\title{
RESEARCH REPORT \\ CONTROLLED BREAKING OF MUMMIFIED WOOD FOR USE IN PALEOENVIRONMENTAL ANALYSIS
}

\author{
BENJAMIN HOOK ${ }^{* 1}$, JOCHEN HALFAR ${ }^{1}$, ZE'EV GEDALOF ${ }^{2}$, and JÖRG BOLLMANN ${ }^{1}$ \\ ${ }^{1}$ Department of Earth Sciences, University of Toronto, Toronto, ON M5S 3B1, Canada \\ ${ }^{2}$ Department of Geography, University of Guelph, Guelph, ON N1G 2W1, Canada
}

\begin{abstract}
The discovery of exceptionally well-preserved Paleogene wood fossils ( $c a$. 55-53 Ma) within Canadian Arctic diamond-bearing kimberlites prompted a paleoclimatic study of the Paleocene-Eocene Transition. The samples are not petrified, but have been "mummified" by their inclusion in pyroclastic debris and still contain primordial wood material. However, preferential cellulose loss has rendered the wood very fragile, precluding the use of standard dendrochronological methods of surface preparation. Similar to archaeological charcoal, breaking the mummified wood allows superior visualization of tree-ring boundaries and wood anatomy, but often produces irregular surfaces making microscopic examination difficult. Therefore, a simple aluminum clamp was constructed to break radial wood transects in a controlled manner for the purpose of collecting dendrochronological and wood-anatomical data for paleoclimatic reconstructions. Because it does not require the use of chemical treatments or stabilizing resins, the wood remains chemically unaltered, allowing chemical and isotopic analyses to be undertaken. Future studies of fragile woods may benefit from this method of controlled breaking if sanding is ineffective.
\end{abstract}

\begin{abstract}
RÉSUMÉ
La découverte de fossiles bois du Paléogène (55-53 Ma), exceptionnellement bien conservés, dans des kimberlites diamantifères dans l'Arctique canadienne a incité à une etude paléoclimatique de la transition Paléocène-Eocène. Les échantillons ne sont pas petrifies. Ils ont été «momifié» de par leur inclusion dans des débris pyroclastiques et contiennent toujours du matériel du bois primordial. Toutefois, la perte de cellulose préférentiel a rendu le bois très fragile, ce qui exclus l'utilisation de méthodes dendrochronologiques usuelles afin de preparer la surface. Comme pour les charbons de bois archéologiques, en brisant le bois momifié, il est possible de visualiser avec acuité les frontières des arbres-anneau et l'anatomie du bois. Cependant, ceci produit souvent des surfaces irrégulières qui rendant l'examen microscopique difficile. Par conséquent, une pince en aluminium simple a été construite afin de briser des transects radiaux de bois de manière contrôlée, dans le but de recueillir des données dendrochronologiques et des données de l'aspect anatomique du bois, afin d'établir des reconstructions paléoclimatiques. Parce que l'utilisation de traitements chimiques ou de résines de stabilisation n'est pas néccessaire, le fossile de bois reste chimiquement inchangé, ce qui permet des analyses chimiques et isotopiques. Les études futures de bois fragiles peuvent bénéficier de notre méthode de rupture contrôlée si le ponçage est inefficace.

Keywords: Paleocene/Eocene transition, non-permineralized fossil wood, fragile wood, surface preparation, automated microscopic scanning, tree-ring measurement, wood anatomy, dendrochronology, paleoclimatology.
\end{abstract}

*Corresponding author: benjamin.hook@utoronto.ca

\section{INTRODUCTION}

"Mummified" woods, which have not been permineralized, are an important paleoclimatic archive. These rare fossils may be found in a 
variety of anoxic burial conditions such as kimberlites (Wolfe et al. 2012), underwater (Lewis et al. 2003), and in tertiary lignite mines (Jahren and Sternberg 2003; Sahay 2011). Because they contain primordial wood material, high-resolution stable isotope studies are possible (Jahren and Sternberg 2008; Csank et al. 2011a, 2011b). However, because of preferential cellulose loss, non-permineralized woods commonly have extremely low cellulose yields (0-10\%) (Jahren and Schubert pers. comm. 2011) resulting in poor structural stability. Consequently, the wood cells are so delicate that any standard preparation tools (saws, razor blades, sandpaper) applied directly to the surface destroy them. Therefore, alternate methods of surface preparation are required for mummified wood.

Several mummified wood fossils were excavated during operations at two kimberlite mines, Rio Tinto's Diavik Diamond Mine $\left(64^{\circ} 29^{\prime} 46^{\prime \prime} \mathrm{N}\right.$, $\left.110^{\circ} 16^{\prime} 24^{\prime \prime} \mathrm{W}\right)$ and BHP Billiton's Ekati Diamond Mine $\left(64^{\circ} 42^{\prime} 49^{\prime \prime} \mathrm{N}, 110^{\circ} 37^{\prime} 10^{\prime \prime} \mathrm{W}\right)$ near Lac de Gras, Northwest Territories, Canada (Wolfe et al. 2012). The kimberlites erupted at $55.5 \mathrm{Ma}$ (Diavik) and 53.6 Ma (Ekati) $\pm 0.6 \mathrm{Ma}$, temporally near the Paleocene-Eocene Thermal Maximum and Elmo hyperthermal events, respectively (Creaser et al. 2004; Heaman et al. 2004; Zachos et al. 2010). Originating from magmatic dykes, pyroclastic debris cooled adiabatically to 25 $400^{\circ} \mathrm{C}$ within hours (Wilson and Head 2007) to days or months (Sparks et al. 2007) after the kimberlite eruption. Fragments of wood and shale xenoliths were instantaneously incorporated up to $>300 \mathrm{~m}$ deep into the emplacement crater (Sweet et al. 2003).

The samples contain primordial wood material, including the oldest stable fossil $\alpha$-cellulose found to date, confirmed by Fourier transform infrared (FTIR) analysis (ANALEST lab, University of Toronto). FTIR absorption peaks of the fossil $\alpha$-cellulose match peaks characteristic of laboratory standard (Sigma-Aldrich) $\alpha$-cellulose $\left(900 \mathrm{~cm}^{-1}\right.$ and $1375 \mathrm{~cm}^{-1}$ ) (Wolfe et al. 2012). The exceptional preservation is likely caused by anaerobic burial in rapidly cooled pyroclastic debris at the time of kimberlite emplacement. However, because of the extreme fragile nature of the material, published surface preparation methods (e.g. Hall 1939; Krusic and Hornbeck 1989; Schweingruber 1990; Jones and Rowe 1999; Angeles 2001; Speer 2010; Donato and Timme 2012) were ineffective for preserving mummified wood cell structures on long radial transects suitable for dendrochronological measurements.

To produce tree-ring width data, it was necessary to preserve these delicate wood cell features on a transverse surface of radial transects similar in size to a standard dendrochronological tree core ( $c a .0 .5 \mathrm{~cm}$ wide, $>10 \mathrm{~cm}$ long). Some methods that work well with small samples $\left(<2 \mathrm{~cm}^{3}\right)$ such as scanning electron microscopy, or epoxy resin embedding and microsectioning could not produce surfaces large enough for treering width measurement (Jones and Rowe 1999). Moreover, we wished to maintain the chemical and isotopic integrity of the wood for subsequent geochemical analyses. Therefore, we tested two methods for viewing the transverse surface: (1) the standard method of cutting, mounting and sanding cross-sections, and (2) controlled breaking of wood transects using a specially-designed breaking machine.

\section{METHODS}

\section{Standard Method (Cutting and Sanding)}

We applied protective media (paraffin or expanding/hardening foam) to the outer circumference of each dried sample to prevent the outer tree rings from flaking off during cutting. Then, we cut cross-sections $(\mathrm{ca} .3 \mathrm{~cm})$ from each sample with a 90-cm finishing saw (Figure 1a). We mounted the sections on backing boards, sanded with progressively finer-grit sandpaper (200 to 2,000 grit), and cleaned the surface with pressurized air (Speer 2010).

\section{Controlled Breaking Method}

Researchers of archaeological charcoal commonly break samples by hand to expose the transverse plane (Schweingruber 1990; Jones and Rowe 1999; Schweingruber and Gärtner pers. comm. 2012). However, manual breaking of the fragile mummified wood was difficult to control 


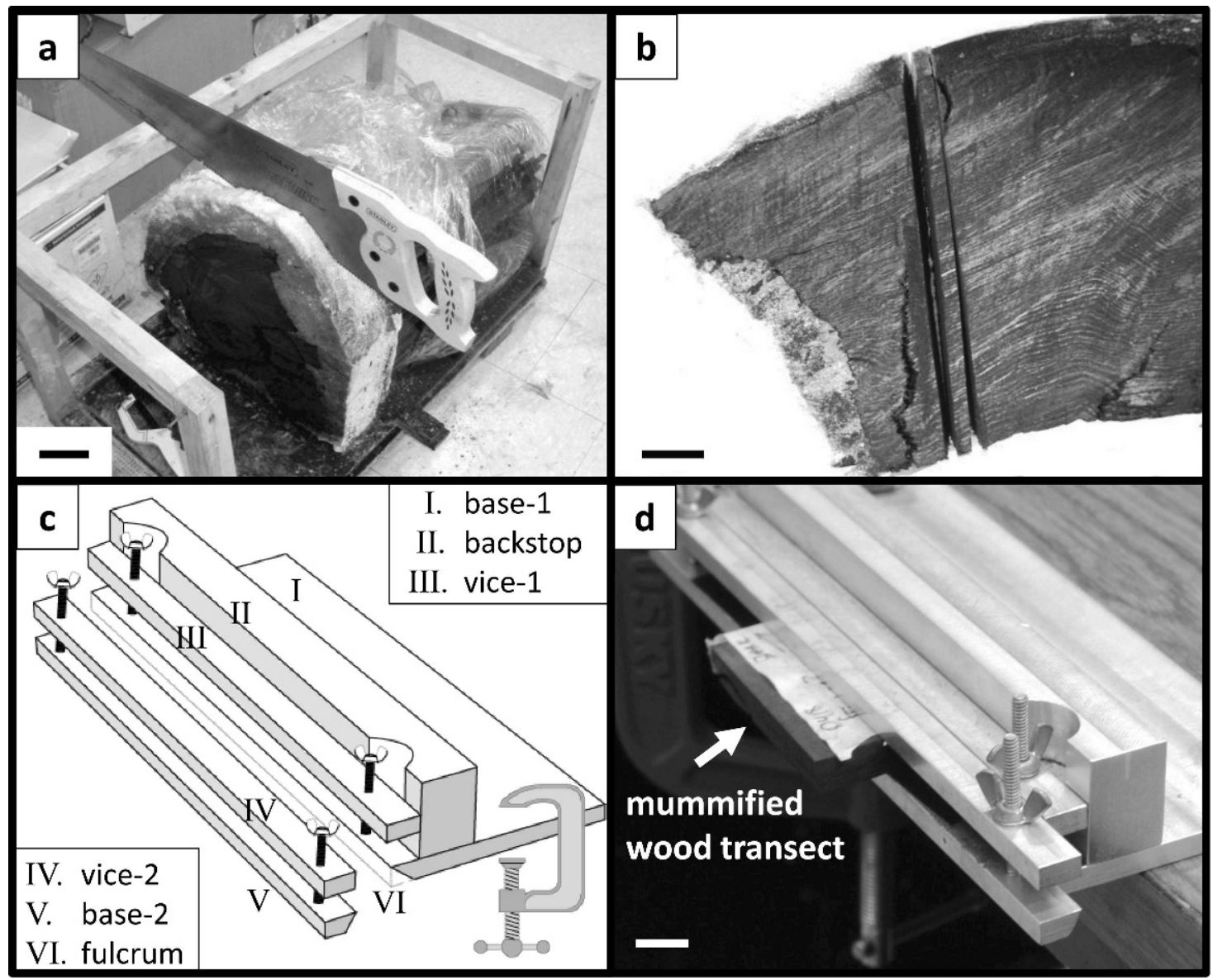

Figure 1. (a) Cardboard forms were used to keep expanding foam within the desired area while hardening overnight, then crosssections $(\mathrm{ca} .3 \mathrm{~cm}$ ) were cut using a fine-toothed saw (scale bar $=20 \mathrm{~cm}$ ). (b) Transects were cut perpendicularly to annual tree-ring boundaries, using masking tape to prevent loss of material during sawing and to enable sample labeling (scale bar $=10 \mathrm{~mm}$ ). (c) Diagram of controlled breaking machine (see Methods section for detailed dimensions of components). Components: I = base-1, II = backstop, $\mathbf{I I I}=$ vice-1, $\mathbf{I V}=$ vice-2, $\mathbf{V}=$ base-2, $\mathbf{V I}=$ fulcrum point (unattached). (d) The controlled breaking machine may be mounted to a lab desk or bench using two large C-clamps. A prepared mummified wood transect is shown in the device, ready to be broken (scale bar $=10 \mathrm{~mm}$ ).

and often resulted in irregular and uneven surfaces. Therefore, we designed a simple machine for the purpose of breaking wood transects in a controlled manner to expose the transverse plane without marring the wood surface. Radial transects (transversal width: $c a$. $0.5 \mathrm{~cm}$; radial-longitudinal height: $2-3 \mathrm{~cm}$ ) were cut from crosssections including pith if present. We then sanded radial surfaces flat, cleaned with compressed air, applied masking tape to both sides of each transect to avoid losing wood fragments during processing, and labeled each transect (Figure 1b). In some cases it was necessary to reconstruct the original cross-section from a series of transects (e.g. if a particular transect was interrupted by an insect gallery). In such cases it was necessary to note top, bottom, inner (pith), and outer (bark) sides of each transect relative to the cross-section to aid in reassembly.

The controlled breaking machine was constructed in the academic machine shop at the University of Toronto at Mississauga from aluminum for a cost of about $\$ 300$ (Figure 1c). It consists of a $200 \times 70 \times 5 \mathrm{~mm}$ "base-1" (n.b. a $45^{\circ}$ wedge was removed from the bottom of the "fulcrum" side - see Discussion section for 
details); a $200 \times 18 \times 25 \mathrm{~mm}$ "backstop" bolted to the base-1, exactly $1 \mathrm{~cm}$ from the fulcrum side (n.b. cylindrical cavities were milled from the backstop to allow space for the wing nuts); a 200 $\times 10 \times 5 \mathrm{~mm}$ "vice-1" attached to the base-1 (fulcrum side) using machine screws and wing nuts; a $200 \times 10 \times 5 \mathrm{~mm}$ "base-2" (n.b. a matching $45^{\circ}$ wedge was removed from the fulcrum side); and a $200 \times 10 \times 5 \mathrm{~mm}$ "vice-2" attached to the base- 2 also using machine screws and wing nuts.

We placed mummified wood transects in the controlled breaking machine between the base-1 and the vice- 1 and tightened the wing nuts firmly, but not so tightly as to induce smashing (Figure 1d). Then we scored both sides of each transect with a razor blade along the edge of the vice-1 (through the tape and $c a .1 \mathrm{~mm}$ into the wood), thus guiding the location of the break. We then attached the base- 2 and vice- 2 firmly to the exposed half of each transect, breaking them manually by pressing downward and inward. Once broken, we mounted the wood using clay such that the longitudinal axis was vertical, and used pressurized air to clean.

We used an automated reflected light microscope (Olympus VS-BX) and geo.TS software (Olympus Soft Imaging Solutions) to capture digital scans of the samples at high-resolution $(50 \times$ to $200 \times$ magnification). This system allows for extended focal depth, by capturing multiple images of a 3D surface (maximum XYZ scanning space: 130 $\times 70 \times 6 \mathrm{~mm})$, assembling a 2D photomosaic (please visit www.utm.utoronto.ca/ w3halfar/ Laboratory.html for further details on automated 3D scanning). A flatbed scanner may also be used if such a 3D scanning system is unavailable; however, areas of wood that are not flat against the surface of the scanner will appear slightly blurred in the final scan. This limitation can be overcome by working with the actual wood sample in conjunction with the digital scan during crossdating and measurement.

A reflected light microscope and measurement stage (e.g. Velmex) could be used to collect linear measurements. However, the mummified wood tree rings in this study were physically compacted. Diagenetic compaction of tree rings was unequally distributed (more common in earlywood than latewood). Therefore, to collect tree-ring width data for this study, measurements were taken along diagenetically deformed ray cell paths. In modern trees, ray cells are normally oriented perpendicularly to annual boundaries, so this is a good approximation of the tree-ring series before compaction.

\section{RESULTS AND DISCUSSION}

In this study, tree-ring widths of consecutive cross-sections of a sample were compared using the two methods described above. Although the sanding method kept cross-sections intact, the sandpaper abraded the wood cells, blurring the surface (Figure 2a). Several annual boundaries were missed altogether that were clearly visible when using the controlled breaking method (Figure 2b). Important wood anatomical features obscured by sanding (Figure 2c) were evident after breaking, including true annual boundaries, resin canals, and "false" rings (Figure 2d). Identification of such features is crucial for accurate crossdating and measurement of tree rings and wood cells, which is critical in our goal of understanding forest ecological processes and climates of ancient environments.

Slight design modifications may be necessary depending on the size and condition of samples. In studies of less-fragile woods, a metal harder than aluminum may provide more stability during breaking. Note that the removal of $c a .45^{\circ}$ of aluminum on the bottom "fulcrum" sides of base1 and base- 2 was essential for proper "hinging" of the transect during breaking. Without this modification, mummified wood transects were more likely to crumble rather than break cleanly because the hinge point was too low. The fixed 1-cm backstop depth produced samples with a consistent height, which is helpful when multiple transects from a cross-section are reassembled. Also, note that applying electrical tape to the "inner" surfaces of both bases and vices helped grip transects during breaking. To avoid uneven breaking, it was important to make sure the radial surfaces of transects were cut parallel and sanded flat. Additional small $(2 \mathrm{~cm}) \mathrm{C}$-clamps may be placed along the base- 2 and vice- 2 to help 


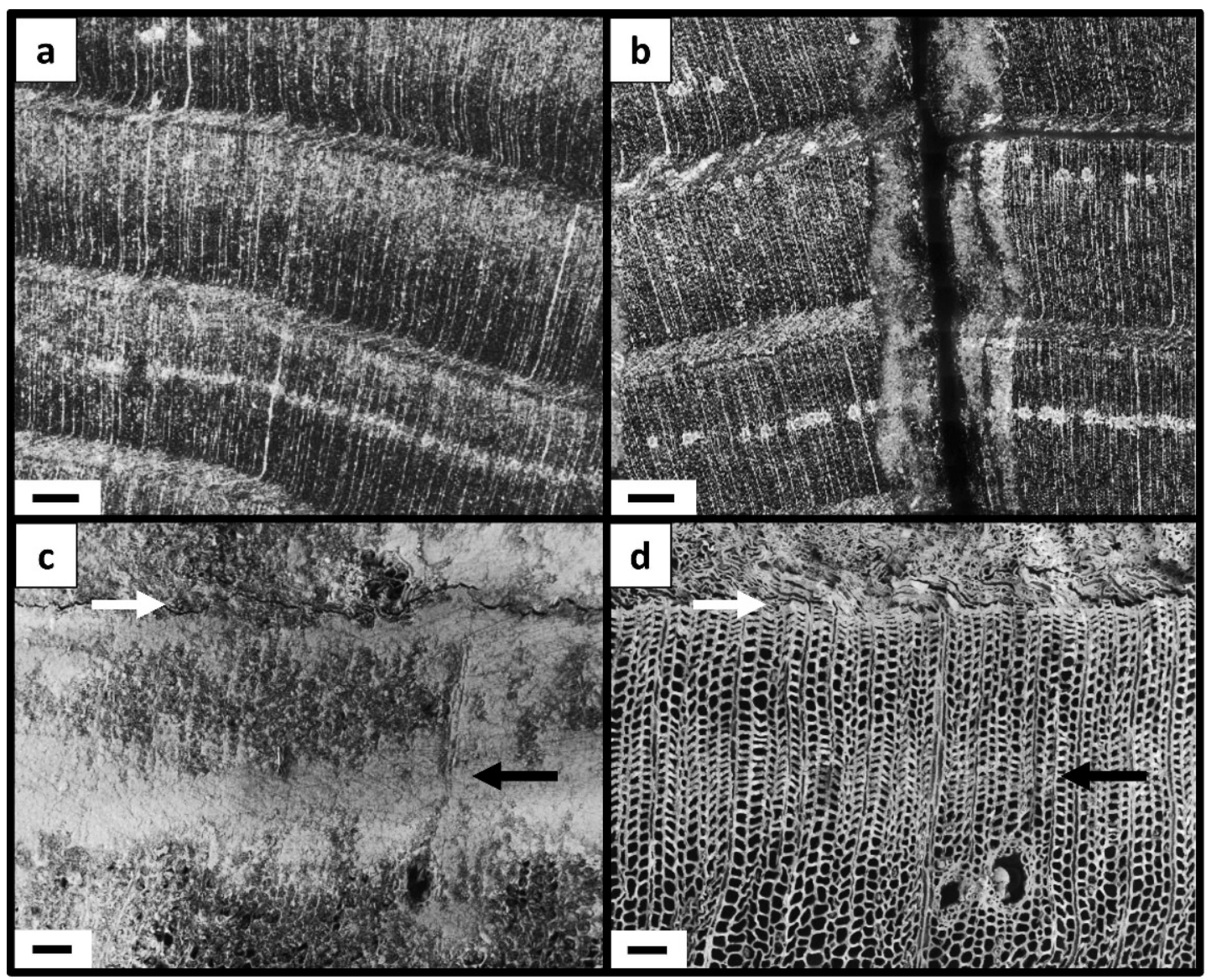

Figure 2. (a) Digital scan of mummified wood after sanding method (scale bar $=1 \mathrm{~mm}$ ). (b) Digital scan of same sample as in (a) after controlled breaking method. Two transects have been reassembled into their original sequence after being cut and scored with a razor blade (scale bar $=1 \mathrm{~mm}$ ). (c) Scanning electron microscope $(\mathrm{SEM})$ image of sample after sanding method (scale bar $=$ $0.1 \mathrm{~mm}$ ). (d) SEM image of the same sample as in (c) after controlled breaking method (scale bar $=0.1 \mathrm{~mm}$ ). Detailed woodanatomical features were apparent in the broken sample (d) which were not visible in the sanded sample (c), including annual boundaries (white arrows), false rings (black arrows), diagenetically crushed earlywood (above white arrows), and resin canals (bottom of $\mathbf{c}$ and $\mathbf{d}$ ).

distribute the force evenly along longer transects, and aid in breaking uniformly.

The unique diagenesis and preservation of mummified wood in kimberlite rock requires alternate methods of surface preparation. The samples may be quite large ( $>60 \mathrm{~cm}$ diameter), but compositionally similar to charcoal because of their rapid entombment in pyroclastic debris. This burial environment is very different from that of most archaeological charcoals, which are usually found as small fragments $(<2 \mathrm{~cm})$ because of taphonomic forces. The method of controlled breaking introduced here allows clear visualization of non-permineralized fossil wood, enabling precise determination of annual tree-ring boundaries along continuous transects, similar to a tree core. This minimally invasive approach leaves the sample unaltered by chemical additives so that subsequent analyses may be conducted. Future studies of fragile wood fossils may benefit from this method of controlled breaking.

\section{ACKNOWLEDGMENTS}

The authors would like to thank Diavik Diamond Mine Inc. (DDMI - Rio Tinto) and 
Ekati Diamond Mine (BHP Billiton) for generous access to the mummified wood, especially David Eichenberg, Hayley McLean, Gus Fomradas, and Yuri Kinakin at DDMI for a tour of Diavik Mine; Peter Duggan (Academic Machine Shop, University of Toronto at Mississauga) for construction of the controlled breaking machine; Marie Puddister (Department of Geography, University of Guelph) for drafting Figure 1c; Hope Jahren and Brian Schubert for discussions about mummified wood cellulose extractions (American Geophysical Union, San Francisco, USA, 2011); Fritz Schweingruber and Holger Gärtner for discussions about wood preparation techniques (International Course on Wood Anatomy, Klosters-Dorf, Switzerland, 2012); Monique Mailloux for assistance with French translation; and two anonymous reviewers whose comments helped to improve the clarity and organization of this manuscript.

\section{REFERENCES CITED}

Angeles, G., 2001. New techniques for the anatomical study of charcoalified wood. International Association of Wood Anatomists (IAWA) Journal 22:245-254.

Creaser, R. A., H. Grutter, J. Carlson, and B. Crawford, 2004. Macrocrystal phlogopite $\mathrm{Rb}-\mathrm{Sr}$ dates for the Ekati property kimberlites, Slave Province, Canada: Evidence for multiple intrusive episodes in the Paleocene and Eocene. Lithos 76: 399-414.

Csank, A. Z., W. P. Patterson, B. M. Eglington, N. Rybczynski, and J. F. Basinger, 2011a. Climate variability in the Early Pliocene Arctic: Annually resolved evidence from stable isotope values of sub-fossil wood, Ellesmere Island, Canada. Palaeogeography, Palaeoclimatology, Palaeoecology 308:339349.

Csank, A. Z., A. K. Tripati, W. P. Patterson, R. A. Eagle, N. Rybczynski, A. P. Ballantyne, and J. M. Eiler, $2011 \mathrm{~b}$. Estimates of Arctic land surface temperatures during the early Pliocene from two novel proxies. Earth and Planetary Science Letters 304:291-299.

Donato, D. C., and S. H. Timme, 2012. A method for surfacing large log cross-sections for scanning and crossdating. TreeRing Research 68(2):115-119.

Hall, E. T., 1939. A method of obtaining a plane surface on charcoal. Tree-Ring Bulletin 5:31.

Heaman, L. M., B. A. Kjaarsgard, and R. A. Creaser, 2004. The temporal evolution of North American kimberlites. Lithos 76:377-397.

Jahren, A. H., and L. S. L. Sternberg, 2003. Humidity estimate for the middle Eocene Arctic rain forest. Geology 31(5): 463-466.

2008. Annual patterns within tree rings of the Arctic middle Eocene ( $c a .45 \mathrm{Ma}$ ): Isotopic signatures of precipita- tion, relative humidity, and deciduousness. Geology 36(2): 99-102.

Jones, T. P., and N. P. Rowe (eds.), 1999. Fossil Plants and Spores: Modern Techniques. The Geological Society, London; $396 \mathrm{pp}$.

Lewis, B. A., J. H. Wrenn, A. J. Lewis, J. J. Alford, and D. Alford, 2003. Middle Winsonsinan and recent wet site mummified wood, humus, peat, and pollen, Santa Rosa Island, Florida. Review of Palaeobotany and Palynology 126: 243-266.

Krusic, P. J., and J. W. Hornbeck, 1989. Preserving decayed wood samples for tree-ring measurement. Tree-Ring Bulletin 49:23-27.

Miller, R. B., 2002. Wood anatomy. McGraw-Hill Encyclopedia of Science \& Technology, $9^{\text {th }}$ ed.

Sahay, V. K., 2011. The hydrocarbon potential, thermal maturity, sequence stratigraphic setting and depositional palaeoenvironment of carbonaceous shale and lignite successions of Panandhro, northwestern Kutch Basin Gujarat, Western India. Central European Journal of Geosciences 3(1): $12-28$.

Schweingruber, F. H., 1990. Microscopic Wood Anatomy: Structural Variability of Stems and Twigs in Recent and Subfossil Woods from Central Europe ( $3^{\text {rd }}$ ed.). K. BaudaisLundström (translator), Swiss Federal Institute for Forest Snow and Landscape Research; 226 pp.

Sparks, R. S. J., R. J. Brown, M. Field, and M. Gilbertson, 2007. Kimberlite ascent and eruption. Nature 450:e21. Comment arising from: L. Wilson and J. W. Head III, Nature 447(3):53-57.

Speer, J. H., 2010. Fundamentals of Tree-Ring Research. University of Arizona Press, Tucson.

Stasiuk, L. D., A. R. Sweet, D. R. Issler, K. Kivi, G. D. Lockhart, and D. R. Dyck, 2003. Pre- and post kimberlite emplacement thermal history of Cretaceous and Tertiary sediments, Lac de Gras, Northwest Territories, Canada. $8^{\text {th }}$ International Kimberlite Conference Long Abstracts. $8^{\text {th }}$ International Kimberlite Conference, Victoria Canada.

Sweet, A. R., L. D. Stasiuk, W. W. Nassichuk, O. Catuneanu, and D. J. McIntyre, 2003. Paleontology and diamonds: Geological environments associated with kimberlite emplacement, Lac de Gras, Northwest Territories, Canada. $8^{\text {th }}$ International Kimberlite Conference Long Abstracts. $8^{\text {th }}$ International Kimberlite Conference, Victoria Canada.

Wilson, L., and J. W. Head, III, 2007. An integrated model of kimberlite ascent and eruption. Nature 447(3):53-57.

Wolfe, A. P., A. Z. Csank, A. V. Reyes, R. C. McKellar, R. Tappert, and K. Muehlenbachs, 2012. Pristine Early Eocene wood buried deeply in kimberlite from northern Canada. PLOS ONE 7(9):e45537.

Zachos, J. C., H. McCarren, B. Murphy, U. Röhl, and T. Westerhold, 2010. Tempo and scale of late Paleocene and early Eocene carbon isotope cycles: Implications for the origin of hyperthermals. Earth and Planetary Science Letters 299:242-249.

Received 20 March 2013; accepted 31 May 2013. 